\title{
DETERMINATION OF THE METHANOGENIC POTENTIAL OF CASSAVA (MANIHOT ESCULENTA CRANTZ) WASTE FROM “ATTIEKE" PRODUCTION IN YAMOUSSOUKRO CITY, COTE D'IVOIRE
}

\author{
KRA Essi Kouadio Francis ${ }^{1 *}$, YAO Leboua ${ }^{1}$, AKICHI Agboue ${ }^{2}$ \\ ${ }^{1 *}$ Mechanics and Materials Science Laboratory, BP 1093 INP-HB Yamoussoukro, Republic of Côte d'Ivoire; \\ ${ }^{2}$ Laboratory of motors and machines for energy conversion, BP 1093 INP-HB Yamoussoukro, Republic of Côte \\ d'Ivoire;
}

*Corresponding Author Kra Essi Kouadio Francis, e-mail: kraessi@gmail.com; francis.kra@inphb.ci;

Received July 2020; Accepted August 2020; Published September 2020;

DOI: https://doi.org/10.31407/ijees10.410

\begin{abstract}
This work focuses on the study of methane productivity from cassava waste (manihot esculenta crantz) from the production of "attiéké" in the city of Yamoussoukro. These wastes are residues recovered from the "attiéké" production units of women's cooperatives in the city of Yamoussoukro. Five reactors or biodigesters (R1, R2, R3, $\mathrm{R} 4$, and R5) were used for the study and operated at an ambient temperature. The quantities of biogas obtained are $404 \mathrm{ml} / \mathrm{kg}(\mathrm{R} 1) ; 460 \mathrm{ml} / \mathrm{kg}(\mathrm{R} 2) ; 480 \mathrm{ml} / \mathrm{kg}(\mathrm{R} 3) ; 444 \mathrm{ml} / \mathrm{kg}$ (R4) and $116 \mathrm{ml} / \mathrm{kg}$ (R5). The respective methane contents are 39.6\%; 46.1\%; 43.3\%; $47.7 \%$ and $41.4 \%$. Biogas production is high in the wet biodigesters (R1 to R4) and low in the reactor containing only solid waste (R5). These results also show that the methane content of the biogas resulting from each mixture is between 39 and $48 \%$. The anaerobic digestion of effluent-peel mixtures produces more biogas with a higher methane content than pure waste. Thus, the ratio of the effluent-peel mixture influences the productivity of the biogas and its methane content.
\end{abstract}

Keywords: biogas, methane, methanogenic potential, cassava waste, reactor, biodigester, reactor. 